\title{
DEVELOPING LEGAL TRANSLATION COMPETENCE: AN INTEGRATIVE PROCESS-ORIENTED APPROACH
}

\author{
Fernando PRIETO RAMOS \\ Translation Professor, University of Geneva \\ ETI, Uni Mail, Bd du Pont-d'Arve 40 \\ CH-1204 Geneva, Switzerland \\ Fernando.Prieto@unige.ch
}

\begin{abstract}
Building on previous holistic multicomponent paradigms of translation macrocompetence, a legal translation competence model is presented which avoids certain conceptual duplications in the light of professional practice, and incorporates distinctive legal thematic elements. Beyond component description, it is argued that the integral development of legal translation competence requires specific interdisciplinary methodologies for practical problem solving. The integrative approach proposed in this paper is process-oriented, and focuses on the legal translation-specific know-how within the key methodological or strategic subcompetence controlling all other subcompetences. Translation and legal knowledge are inextricably linked throughout the translation process, from the initial skopos analysis and legal macro-contextualization until the final revision stage. This approach, intended as a meta-reflection continuum between competence acquisition and reinforcement, and between formal training and professional practice, has proved effective for the systematization of problem-identification, problemcategorization and problem-solving patterns. Finally, some implications for legal translation training are outlined by way of conclusion.
\end{abstract}

Keywords: legal translation, competence development, translation process, translation problem solving, translator training

\section{EL DESARROLLO DE LA COMPETENCIA EN TRADUCCIÓN JURÍDICA: UN ENFOQUE INTEGRADOR ORIENTADO AL PROCESO}

Resumen: Partiendo de anteriores paradigmas multicomponenciales holísticos de macrocompetencia traductora, se presenta un modelo de competencia en traducción jurídica que evita ciertas duplicaciones conceptuales en vista de la práctica profesional, e incorpora elementos de temática jurídica distintivos. Más allá de la descripción de componentes, se argumenta que el desarrollo integral de la competencia en traducción jurídica exige metodologías interdisciplinares específicas para la resolución de problemas prácticos. El enfoque integrador que se propone en el presente artículo está orientado al proceso y hace hincapié en los conocimientos especializados propios de la traducción jurídica incluidos en la subcompetencia metodológica o estratégica, subcompetencia clave que controla las demás. Los conocimientos traductológicos y jurídicos se entrelazan inextricablemente a lo largo del proceso traductor, desde el análisis del skopos y la macrocontextualización jurídica iniciales hasta la fase final de revisión. Este enfoque, concebido como un continuo metarreflexivo entre la adquisición y el fortalecimiento de competencias y entre 
la capacitación formal y la práctica profesional, ha resultado eficaz para sistematizar pautas de detección, categorización y resolución de problemas. Por último, a modo de conclusión, se esbozan algunas consideraciones sobre la formación en traducción jurídica.

Palabras clave: traducción jurídica, desarrollo de competencias, proceso traductor, resolución de problemas de traducción, formación de traductores

\section{Competence-based approaches to translation}

Since the 1990s, the study of translation competence has been stimulated by the proliferation of university programmes and research in translation. It has gained momentum within the framework of the Bologna reform in Europe in recent years, as reflected in the competence-based approach of the European Master's in Translation (EMT).

In spite of the different perspectives, consensus has grown in the past two decades around some elements of the so-called "competence-based training" (see e.g. Hurtado Albir 2007). Firstly, the need to orientate translator training programmes to the development of professional skills (see e.g. Hurtado Albir 1999 or Schäffner 2000). Secondly, the perception of translation competence as a complex "macrocompetence" (e.g. Kelly 2002, 14) or "supercompetence" (e.g. Wilss 1976, 120) comprising several competences, subcompetences or skills. ${ }^{1}$ Thirdly, studies on translation competence have progressively expanded the list of core components of translation macrocompetence. During the 1990s, authors like Nord (1991), Delisle (1992), Gile (1995), Kiraly (1995) and Neubert (2000), albeit using different labels and divisions, identified similar key competences. These can be summarized as follows by combining Nord's $(1991,235)$ account of "essential competences required of a translator" and Neubert's $(2000,6)$ taxonomy of "parameters of translational competence": (1) language competence; (2) textual competence (text reception and analysis, production and quality assessment); (3) subject or thematic competence; (4) cultural competence; (5) research competence; (6) transfer competence.

Since the late 1990s, the PACTE Group, led by Amparo Hurtado Albir, has been conducting research on translation competence components with a view to applying their model to the empirical-experimental study of competence acquisition (PACTE 2000, 2003, 2005). Drawing on cognitive approaches, they identify new components. In the improved version of their model, translation competence is described as "the underlying knowledge system needed to translate" (PACTE 2005, 610), and is made up of five interrelated subcompetences and psycho-physiological components:

The bilingual sub-competence is made up of pragmatic, socio-linguistic, textual and lexical-grammatical knowledge in each language. The extra-linguistic subcompetence is made up of encyclopaedic, thematic and bicultural knowledge. The translation knowledge sub-competence is knowledge of the principles that guide

\footnotetext{
${ }^{1}$ For ease of reading, "competence" is used in this paper interchangeably with "macrocompetence" or "subcompetence" depending on the context.
} 
translation (processes, methods and procedures, etc.) and the profession (types of translation briefs, users, etc.). The instrumental sub-competence is made up of knowledge related to the use of documentation sources and information technologies applied to translation. The strategic sub-competence is the most important, as it is responsible for solving problems and the efficiency of the process. It intervenes by planning the process in relation to the translation project, evaluating the process and partial results obtained, activating the different sub-competencies and compensating for deficiencies, identifying translation problems and applying procedures to solve them. The psycho-physiological components are cognitive and behavioural (memory, attention span, perseverance, critical mind, etc.) and psychomotor mechanisms (PACTE 2005, 610; emphasis added).

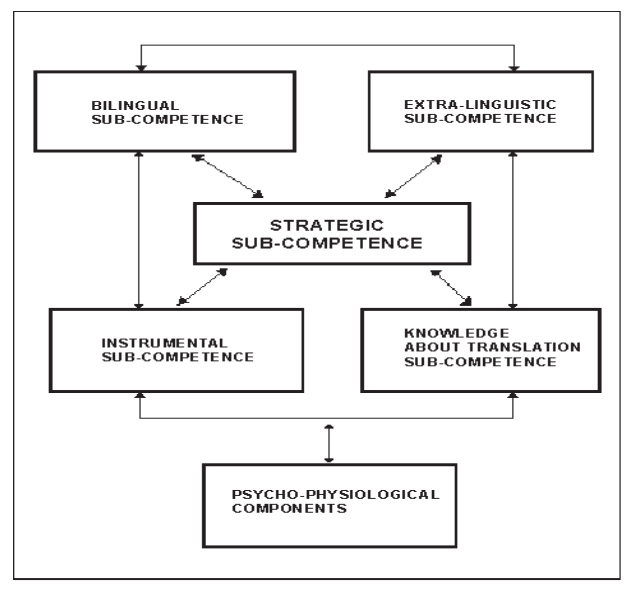

Figure 1. PACTE Group translation competence model (ibid., 610)

Other than the new information technology and psycho-physiological components, and the distinction between the translation knowledge competence and the strategic competence, the main contribution of the PACTE model lies in highlighting the relevance of the latter as procedural knowledge needed to activate the other competences for problem solving, beyond more limited paradigms of transfer competence. This central role was first underlined by Neubert, for whom "transfer competence is the distinguishing domain of a translator"; it "dominates over all the other competences" $(2000,6)$. However, the PACTE Group also considers other competences as translation-specific: "Given that any bilingual has knowledge of two languages and may have extra-linguistic knowledge, we consider that the sub-competencies specific to TC [translation competence] are the strategic, the instrumental and knowledge about translation" (PACTE 2005, 611). The inclusion of instrumental competence in the list is clearly the result of new technological developments in the field, while the distinction between the strategic and the translation knowledge competences seems more arbitrary, as we will argue below. 
Largely inspired by the PACTE Group, Kelly (2002) agrees on the prominent procedural role of strategic subcompetence, which she places at the top of her pyramidal model. She distinguishes between thematic and cultural subcompetences (grouped under "extra-linguistic competence" in the PACTE model), rather than between strategic and translation knowledge subcompetences, and she adds the interpersonal subcompetence necessary for professional practice (ability to interact with other translators, professionals, clients, etc.).

In spite of some criticisms of the complexity and academicism of multicomponent competence models, ${ }^{2}$ most authors now agree on the advantages of these paradigms for the systematic description of the activities carried out and analyzed in our field, particularly for curriculum-design purposes (e.g. Kelly 2002, 16). For Hurtado Albir (2007, 166), competence-based training offers "greater transparency of professional profile in study programmes, greater emphasis on the outcome of learning, more flexibility and a greater integration of all aspects of a curriculum". It is in fact this approach that has been enshrined by the EMT reference framework in an attempt to put forward "a minimum quality profile", fearing that some of the recently-launched translation programmes "may exist in name only, owing to a lack of analysis of requirements, a lack of understanding of the demands of the profession, and a lack of qualified teachers" (EMT Expert Group 2009, 1).

Within that framework, "competence" is defined as "the combination of aptitudes, knowledge, behaviour and know-how necessary to carry out a given task under given conditions". Six interdependent competences are identified:

- Translation service provision competence (interpersonal and production dimensions)

- $\quad$ Language competence

- Intercultural competence (sociolinguistic and textual dimensions)

- Information mining competence

- Thematic competence

- Technological competence

${ }^{2}$ For instance, Pym $(2003,487)$ notes that this kind of model "is obviously a response to interdisciplinarity and the break with linguistics; but institutionally it operates as a political defence of a certain model of translator training. And that model is not the only one, nor necessarily the best".

${ }^{3}$ They argue that "following the Bologna Declaration, with particular reference to employability, a number of universities launched a translation programme, often with the aim of recycling or of renewing their language teaching" (ibid., 1). 


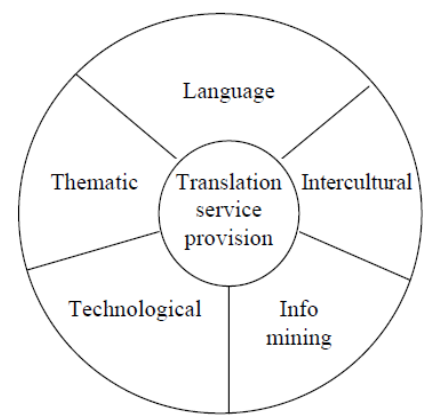

Figure 2. EMT Expert Group translation competence model (ibid., 4)

If we look into the components of the production dimension of the translation service provision competence, we find that this competence equates to the strategic competence in other models:

- Knowing how to create and offer a translation appropriate to the client's request, i.e. to the aim/skopos and to the translation situation

- Knowing how to define stages and strategies for the translation of a document

- Knowing how to define and evaluate translation problems and find appropriate solutions

- Knowing how to justify one's translation choices and decisions

- Mastering the appropriate metalanguage (to talk about one's work, strategies and decisions)

- Knowing how to proofread and revise a translation (mastering techniques and strategies for proofreading and revision)

- Knowing how to establish and monitor quality standards (ibid., 5).

In fact, the translation service provision competence features at the centre of the EMT model. For example, "the aptitude for taking reasoned decisions is horizontal; it applies equally to the provision of a translation service and to documentary research" (ibid., 3). It is also made clear that the six competences identified "comprise the minimum requirement to which other specific competences may be added (for example in localisation, audiovisual translation or research)" (ibid., 3). This brings us to the question of which specific components characterize legal translation competence.

\section{Towards a legal translation competence model}

The models presented above are useful in outlining the core skills that must be applied in any specialized translation, including legal translation. Nonetheless, in order for them to work efficiently, they must be enriched with the specific interdisciplinary elements of each branch of translation (in the case of legal translation, with particular attention to legal thematic competence), and they must be integrated into adequate methodological 
models for professional practice and competence development (in our case, through a solid legal translation-oriented methodological competence).

Anchored on the assumption of usefulness of multicomponent competence descriptions, our holistic model is informed by professional practice and previous paradigms, notably those of the PACTE Group, Kelly and the EMT Expert Group. It avoids certain unnecessary duplications, and rather aims at simplifying reference to professional skills. Cultural and thematic competences are grouped together (as in PACTE's "extra-linguistic subcompetence"), as are strategic and translation knowledge competences, while psycho-physiological components are integrated into a wider interpersonal and professional management competence. ${ }^{4}$ All five competences are oriented to legal translation under the coordination of the key strategic or methodological competence:

- Strategic or methodological competence, which controls the application of the other skills and comprises: analysis of translation briefs, macro-contextualization and general work planning, identification of problems and implementation of transfer strategies (translation procedures), decision-making argumentation, self-assessment and quality control (for more details, see section 3 below).

- Communicative and textual competence: linguistic, sociolinguistic and pragmatic knowledge, including knowledge of linguistic variants, registers, specialized legal linguistic uses and legal genre conventions.

- $\quad$ Thematic and cultural competence: knowledge of legal systems, hierarchy of legal sources, branches of law and main legal concepts; awareness of asymetry between legal notions and structures in different legal traditions.

- Instrumental competence (documentation and technology): knowledge of specialized sources, information and terminology management, use of parallel documents, application of computer tools to translation.

- Interpersonal and professional management competence: teamwork, interaction with clients and other professionals, knowledge of legal framework for professional practice and fiscal obligations, deontological aspects.

The five competences comprise declarative and operative knowledge to a greater or a lesser extent. Given its central role in putting different skills at the service of concrete translation tasks, methodological competence is the most procedural in

4 On initiatives illustrating the interplay between these components within interpersonal competence (group perceptions, self-confidence, interaction between translators and legal experts), see Rayer 1991 and Way 2002. 
nature, but it also draws on its own specific declarative knowledge of the translation process and problem-solving procedures (what the PACTE Group isolates as "translation knowledge competence").

The above breakdown reflects the interdisciplinarity of translation macrocompetence components in general, and the interplay between law and translation in the case of legal translation. In that context, as in any specialization, thematic competence constitutes a distinctive feature of legal translation competence. The core of that subcompetence would be very close to the practical principles of comparative law (contrastive analysis of concepts in different legal systems). However, other elements of legal science and legal linguistic knowledge impregnate legal translation competence:

- Scope of specialization: classification of legal genres (textual competence);

- Comparative legal linguistics: features of legal discourse in the source and the target languages and jurisdictions (communicative and textual competence);

- Documentation: specialized legal sources (instrumental competence);

- Professional practice: market conditions, associations and deontology issues in legal translation (interpersonal and professional management competence).

Even if legal translators do not need to be equipped with a jurist's level of legal expertise, it is essential that they acquire sufficient legal knowledge in order to situate the documents in their legal and procedural context, as well as to grasp the legal effects of original and target texts. In fact, legal translation between national systems normally entails an exercise of comparative law before any translation procedure can be applied to culturally-marked segments on reasoned grounds. The legal translator must try to understand and produce legal texts with "lawyer-linguist" eyes (if we adopt the term employed for legal translators at the Court of Justice of the European Union), i.e. s/he must be familiar with rules of interpretation, legal reasoning, legal structures and procedures, common legal phraseology, and legal sources used by jurists. For instance, in the case of international and supranational legal systems, their renderings will often become binding law, and their role as legal drafters forces them to address textual ambiguities according to international rules of legal interpretation.

Through specialization in specific areas of legal practice, the legal translator can actually get to develop some subcompetences (knowledge and skills mentioned above) also present in the legal professional working in the area in question, even if at different levels and for different purposes. The deeper the knowledge of legal subjects, the more confident the translator can feel when dealing with legal content issues during analysis and transfer stages of translation; and, as the argument reasonably goes, those trained in both translation and law potentially make the best legal translators. Nonetheless, most legal translation experts also agree that it is more realistic to aim at interdisciplinary legal translation training programmes integrating law courses for the development of thematic competence (see e.g. Šarčević 1997, 113-115). This 
precondition is a crucial step in the right direction, but not enough to ensure sound decision-making in legal translation. It is in legal translation courses that translation and law, and all competences reinforced in other courses, must be integrated and put into practice through legal translation-specific methodologies. The proposal outlined below explores avenues in that direction.

\section{Methodology for competence development in legal translation}

No matter how well one defines skill components, success in building legal translation competence is far from assured without the methodological know-how necessary to activate and coordinate all relevant components in problem solving. Not always sufficiently valued in Translation Studies, ${ }^{5}$ methodological competence is the engine that makes the whole translation machinery work; it lies at the very heart of the specificity of professional translation practice and training. As specified above, it entails the mastery of all stages of the translation process from the analysis of the translation brief to quality control, i.e. essentially a process of problem identification and solving, as Kaiser-Cooke $(1994,137)$ well expressed it: "From the perspective of an expert activity, translation is primarily a problem-solving activity, which involves problem recognition as well as decision-making, since recognition of the problem necessarily precedes decisions as to the various strategies which can be taken to solve it".

Our integrative methodology for legal translation practice is nourished by the experience of both professional legal translation in different contexts and teaching at university level, particularly in legal translation courses of the Master's degree in Translation at the University of Geneva. The model is accordingly oriented to both competence acquisition and competence reinforcement. As verified in our experience, the same systematization of methods and problem-solving strategies analyzed in training stages of practice can later prove essential for coherent decision-making in professional practice, and it is in professional scenarios (whether real or simulated) that our methodology has been tested with very positive results. Rather than presenting all stages of the translation process in much detail, we will offer an overview, emphasizing the legal translation-specific features with a view to identifying the most distinctive elements that could be incorporated into other paradigms.

\section{a) Analysis of skopos and macro-contextualization}

\footnotetext{
5 "Dealing with this practical methodology of translation, which has always played a major role in the classroom, has often been discarded by translation theorists as too practicist and even trivial" (Neubert 1994, 416).
} 
This comprises the analysis of the translation brief, including the type of translation, and the communicative situation and purpose of both source and target texts, as well as their contextualization according to three parameters, from more general to more specific (see Prieto Ramos 2009):

- legal system (i.e. linguistic and geographical coordinates of jurisdictions): this will allow us to determine whether we are mediating in an international legal framework, within a multilingual system or between national systems with different linguistic variants and divergent legal concepts; for instance, the translation of a divorce judgment by a Californian court for Mexico will be different from an Irish divorce judgment whose translation is needed in Venezuela;

- branch of law (i.e. thematic and statutory coordinates): this will activate knowledge of applicable legal sources and main legal concepts relevant to the translation; in the previous example of the divorce judgment, we will immediately refer to the main sources in family law within the legal systems identified;

- legal text typology according to the discursive situation (legislative, judicial, administrative, etc.), and more specifically, the legal genre ${ }^{6}$ (as textual realization of a specific legal function following established conventions in a particular sociocultural context); this parameter will help identify the procedural raison d'être, legal effects and formal discursive conventions of particular genres, before identifying conventions in parallel texts fulfilling the same functions.

This first contextualization will provide an adequate framework for overall strategy design at macrotextual level, and for detecting, categorizing and solving translation problems at microtextual level. Furthermore, it already activates thematic, textual and instrumental competence relevant to the specific translation job.

\section{b) Source text analysis}

Apart from verifying the key features of the source text in terms of coherence, cohesion and style (legal linguistic elements), the translator must perfectly understand the legal function of the text, and identify any comprehension problems. In order to grasp legal meaning as intended by specialized authors, s/he must primarily rely on legal sources (and legal experts or authors if necessary and/or possible), rather than dictionaries or secondary sources, and s/he should ideally be familiar with legal reasoning (or legal argumentation; see e.g. Hage 1997) and principles of legal hermeneutics (e.g. applicable rules of interpretation in the case of international treaties; see Prieto Ramos 2011). Such

${ }^{6}$ Genre classification requires a great deal of flexibility, since the same genre can refer to different legal branches, paralegal genres can also deal with legal concepts (for example, an opinion article on trade dispute settlement), and multiple subclassifications of particular genres are possible. 
skills are paramount in detecting and addressing ambiguity problems, as well as in instrumental legal information mining throughout the translation process, beyond the analysis of the source text. Needless to say, given the legal force of many legal texts, the translator must be particularly alert in scrutinizing semantic nuances in order to scrupulously convey them in reformulation.

\section{c) Transfer and target text production}

At this stage the translator must typically deal with interrelated terminological, procedural and discursive difficulties in order to produce the target text.

Terminological or conceptual problems are usually posed by the differing levels of equivalence between legal concepts in the source and target legal systems (for example, the organization of judicial institutions in different national jurisdictions). In those instances, the translator must first engage in an exercise of comparative law. As pointed out by de Groot $(2006,424)$, "Translators of legal terminology are obliged to practise comparative law. [...] Through comparative law, the translator of legal terminology needs to find an equivalent in the target language legal system for the term of the source language legal system" (for recent examples of comparative legal analysis in translation, see e.g. Bestué Salinas 2008 or Ferran Larraz 2009).

Once the degree of equivalence between legal concepts is established, problems of terminological congruency must be solved through the application of translation procedures adequate to the skopos (on degrees of equivalence and procedures to compensate for terminological incongruency in legal translation, see e.g. Šarčević 1997, 229-269). The activation of preliminary knowledge of adequacy of source-oriented and/or target-oriented solutions after the initial macro-contextualization will have previously served to prioritize certain procedures in the overall translation strategy. In translation between legal systems, "neutral" renderings, borrowings and solutions combining literal formulations with lexical expansions are commonplace in order to accurately convey the specificity of source system-bound concepts, while allowing for target text comprehension. This encapsulates, for many, the defining challenge of translation between legal systems, in Biel's words $(2009,187)$, "a hybrid where the source language text is accessed through target language knowledge structures". However, the priorities of documentary translation between legal systems (where we commonly do not pretend to be producing a non-translated document, but may rather be expected to offer a meticulous rendering of a source text for purposes different to those of the original) can differ enormously from instrumental legal translation in an international framework, where conceptual unity, terminological harmonization and formal concordance tend to be prioritized.

Other problems related to stylistic rather than semantic aspects of reformulation usually arise when drafting the target text (e.g. established formulas, syntactic complexities, structural features). In translation between two legal systems, 
such problems often demand measuring the level of correspondence between discursive conventions of the text type and legal genre in question in both systems through exploration of parallel texts and related sources previously identified. This exercise of applied comparative legal linguistics should be based on previously acquired knowledge of key features of legal language and legal genres in the context analyzed (see e.g. comparison of legal German, legal French and legal English in Mattila 2006). Special attention must be paid to microtextual markers of legal enforceability, such as modal verbs in English, whereas decision-making regarding established phraseology and other formal conventions will depend on the relevance of the particular text segment, on the level of interlinguistic idiomatic correspondence, and crucially on target reader expectations.

\section{d) Revision}

As in any other branch of translation, in this critical final phase of the translation process, ${ }^{7}$ the overall adequacy of the target text to its skopos must be carefully verified. Quality control in legal translation requires particular emphasis on accuracy and effectiveness of legal communication when assuring the macrotextual coherence of solutions to the semantic, procedural and reformulation problems encountered.

\section{Implications for training}

From a pedagogical point of view, global simulations of translation jobs with real legal texts in real professional conditions are the best possible exercises for methodology application in legal translation courses at advanced level. Process-oriented approaches constitute the appropriate framework to expose the trainee translator to a variety of legal text types and legal translation argumentation necessary to assimilate background knowledge to be later applied and adapted to new translation scenarios by analogy. It is through practice that cognitive frames are built which allow the translator to situate legal texts, and identify, categorize and solve translation problems more efficiently in those scenarios. In other words, the assimilation and predictability of translation regularities through such frames have a positive impact on proficiency and productivity (on cognitive aspects of "translatorial expertise", see e.g. Kaiser-Cooke 1994 ${ }^{8}$ ).

\footnotetext{
${ }^{7}$ Perceived here as a circular process along the lines of Nord's (1991) "looping model".

${ }^{8}$ She rightly notes that problem recognition "is a salient feature of expertise; we are all familiar with novices or laypersons who describe texts as 'easy to translate' because they are not aware of the difficulties (i.e. the nature of the problem) involved". She refers to "explicit, face value" perception of problems by novices as opposed to experts, "whose knowledge is organized around inferences about principles and abstractions, categorise problem at a higher, more abstract level" (Kaiser-Cooke 1994, 137).
} 
Systematic reflection on the translation process through practice must be particularly explicit in the case of trainee translators in order to consolidate strategic competence. That reflection will help reinforce procedural skills to overcome deficiencies and improve performance. Subsequent practice and specialization in certain branches and legal genres may lead to expert performance in specific contexts, often including cognitive automation in the application of adequate problem-solving strategies.

\section{Conclusions}

Far from old misconceptions of translation as a derivate of language competence, converging multicomponent models of translation macrocompetence have shed light on what makes a good translator and what specific skills should be reinforced in specific training programmes. Building on certain shared views from generic models, our analysis of legal translation competence underscores the complexity and high level of interdisciplinarity of this branch of translation. The model not only integrates the characteristic legal thematic elements of the specialization, but is also accompanied by a distinctive process-oriented proposal for application of methodological or strategic competence as central coordinating competence. Without adequate procedural skills to successfully interconnect relevant knowledge (including legal knowledge) in translation problem solving, this knowledge could remain scattered, compartmentalized and/or inoperative.

Beyond the benefits anticipated by Alves (2005) in relation to dynamic models bridging the gap between declarative and procedural knowledge, the integrative process-oriented approach presented here allows for systematization of problemidentification, problem-categorization and problem-solving patterns, in turn channeling a meta-reflection continuum between training and professional stages of practice, and between acquisition and advanced levels of competence. Nonetheless, the implications for formal training are particularly relevant. While non-academic training can certainly be effective, and even necessary, in the adaptation of translation skills to specific translation scenarios, the complexity of legal translation competence and the high variability of those scenarios call for formal interdisciplinary training in order to establish solid methodological pillars for subsequent competence development. Otherwise, the lack of meta-reflection on strategic patterns can lead to erratic or superficial problem-solving. Furthermore, comprehensive interdisciplinary training should contribute significantly to the legal translator's self-confidence and awareness of professional specificity.

Two further implications derive from the above. Firstly, as regards trainers, the pedagogical implementation of truly interdisciplinary methods requires a considerable level of preliminary competence in translation and law. Both practitioners and academics in the field should acknowledge deficiencies owing to the lack of 
comprehensive tailor-made training (including of legal translation trainers themselves, as evidenced e.g. by Mayoral Asensio 2005), and take measures in order to overcome such deficiencies in cooperation with jurists. Secondly, as far as trainees are concerned, generalizations according to which law graduates are better candidates for legal translation than translation graduates are rather simplistic. Assuming that legal translation reasonably requires postgraduate specialization, the starting level in each subcompetence to be developed can vary enormously depending on the individual profile. In broad terms, however, those with a (national) legal background can be expected to have a very strong thematic competence (even if often lacking essential comparative legal components), but also important deficiencies in key linguistic, textual and strategic competences; whereas the reverse might be the case for translation graduates. In any event, the ultimate challenge within the interdiscipline would be to produce highly competent legal translators through comprehensive legal translation training rather than presuming expert performance only from a double parallel qualification in translation and law.

\section{Bibliography}

Alves, Fabio. 2005. Bridging the Gap Between Declarative and Procedural Knowledge in the Training of Translators: Meta-Reflection Under Scrutiny. Meta 50(4) [article only available in electronic form]. http://www.erudit.org/revue/meta/2005/v50/n4/019861ar.pdf.

Bestué Salinas, Carmen. 2008. El método comparativo en la traducción de textos jurídicos. Úsese con precaución. Sendebar 19: 199-212.

Biel, Łucja. 2009. Organisation of background knowledge structures in legal language and related translation problems. Comparative Legilinguistics 1: 176-189.

De Groot, Gérard-René. 2006. Legal Translation. In: Jan M. Smits. Elgar Encyclopedia of Comparative Law. Cheltenham: Edward Elgar Publishing, 423-433.

Delisle, Jean. 1992. Les manuels de traduction: essai de classification. TTR (traduction, terminologie, rédaction) 5(1): 17-47.

EMT Expert Group. 2009. Competences for professional translators, experts in multilingual and multimedia communication. Brussels: European Commission. $\mathrm{http} / /$ ec.europa.eu/dgs/translation/programmes/emt/ key_documents/emt_competences_translators_en.pdf.

Ferran Larraz, Elena. 2009. La institución desconocida y la intraducibilidad. Paralelismo entre el derecho comparado y la traducción jurídica frente a la intraducibilidad. Meta 54(2): 295-308.

Gile, Daniel. 1995. Basic Concepts and Models for Interpreter and Translator Training. Amsterdam: John Benjamins.

Hage, Jaap C. 1997. Reasoning with Rules. Dordrecht: Kluwer.

Hurtado Albir, Amparo (dir.). 1999. Enseñar a traducir: metodología en la formación de traductores e intérpretes. Madrid: Edelsa. 
Hurtado Albir, Amparo. 2007. Competence-based Curriculum Design for Training Translators. The Interpreter and Translator Trainer 1(2): 163-195.

Kaiser-Cooke, Michèle. 1994. Translatorial expertise - a cross-cultural phenomenon from an inter-disciplinary perspective. In: Mary Snell-Hornby, Franz Pöchhacker and Klaus Kaindl (eds.). Translation Studies. An Interdiscipline. Amsterdam: John Benjamins, 135-139.

Kelly, Dorothy. 2002. Un modelo de competencia traductora: Bases para el diseño curricular. Puentes 1: 9-20.

Kiraly, Donald. 1995. Pathways to Translation. Pedagogy and Process. Kent, Ohio: Kent State University Press.

Mattila, Heikki E. S. 2006. Comparative Legal Linguistics. Aldershot: Ashgate.

Mayoral Asensio, Roberto. 2005. ¿Cuánto Derecho debe saber el traductor jurídico? In: Esther Monzó and Anabel Borja (eds.). La traducción y la interpretación en las relaciones jurídicas internacionales. Castellón: Universitat Jaume I, 107-112.

Neubert, Albrecht. 1994. Competence in translation: a complex skill, how to study and how to teach it. In: Mary Snell-Hornby, Franz Pöchhacker and Klaus Kaindl (eds.). Translation Studies. An Interdiscipline. Amsterdam: John Benjamins, 411-420.

Neubert, Albrecht. 2000. Competence in language, in languages, and in translation. In: Christina Schäffner and Beverly Adab (eds.). Developing Translation Competence. Amsterdam: John Benjamins, 3-18.

Nord, Christiane. 1991. Text Analysis in Translation. Theory, Methodology, and Didactic Application of a Model for Translation-Oriented Text Analysis. Amsterdam: Rodopi.

PACTE. 2000. Acquiring translation competence: hypotheses and methodological problems of a research project. In: Allison Beeby, Doris Ensinger and Marisa Presas (eds.). Investigating Translation. Amsterdam: John Benjamins, 99-106.

PACTE. 2003. Building a Translation Competence Model. In: Fabio Alves (ed.). Triangulating Translation: Perspectives in Process Oriented Research. Amsterdam: John Benjamins, 43-66.

PACTE. 2005. Investigating Translation Competence: Conceptual and Methodological Issues. Meta 50(2): 609-619.

Prieto Ramos, Fernando. 2009. Interdisciplinariedad y ubicación macrotextual en traducción jurídica. Translation Journal 13(4).

http://translationjournal.net/journal/50legal.htm.

Prieto Ramos, Fernando. 2011. El traductor como redactor de instrumentos jurídicos: el caso de los tratados internacionales. Journal of Specialised Translation 15 (forthcoming).

Pym, Anthony. 2003. Redefining Translation Competence in an Electronic Age. In Defence of a Minimalist Approach. Meta 48(4): 481-487.

Rayer, Louise. 1991. The Limburg Combined Course for Lawyers and Translators. In: Catriona Picken (ed.). ITI Conference 5: Windows on the World: Proceedings. London: ASLIB, 12-23.

Šarčević, Susan. 1997. New Approach to Legal Translation. The Hague: Kluwer Law International. 
Schäffner, Christina. 2000. Running before Walking? Designing a Translation Programme at Undergraduate Level. In: Christina Schäffner and Beverly Adab (eds.). Developing Translation Competence. Amsterdam: John Benjamins, 143-156.

Way, Catherine. 2002. Traducción y Derecho: iniciativas para desarrollar la colaboración interdisciplinar. Puentes 2: 15-26.

Wilss, Wolfram. 1976. Perspectives and limitations of a didactic framework for the teaching of translation. In: Richard Brislin (ed.). Translation Applications and Research. New York: Gardner, 117-137. 
